\title{
MATHEMATICAL MODELS FOR ESTIMATING METHANE PRODUCTION IN COVERED LAGOON BIODIGESTERS TREATING PIG MANURE
}

\author{
Juciara O. Lopes ${ }^{1}$, André P. Rosa ${ }^{1}$, Izabelle de P. Sousa ${ }^{1}$, \\ Nathalia S. Oliveira ${ }^{1}$, Alisson C. Borges ${ }^{1}$
}

${ }^{1 *}$ Corresponding author. Universidade Federal de Viçosa/ Viçosa - MG, Brasil.

E-mail: andrerosa@ufv.br | ORCID ID: https://orcid.org/0000-0001-5490-5698

\section{KEYWORDS}

biogas, pig manure, anaerobic digestion, modeling.

\begin{abstract}
Covered lagoon biodigesters (CLB) have been widespread in Brazil in the treatment of pig manure. However, the quantification of biogas production in CLB using mathematical models is still limited and scarce. This study aimed to evaluate and compare six mathematical models-Chen-Hashimoto (Chen, 1983), CETESB (2006), COD Conversion (Chernicharo, 2016), IPCC (2006), Deng (Deng et al., 2014), and modified Stover-Kincannon ( $\mathrm{Yu}$ et al., 1998) - usually used to estimate methane $\left(\mathrm{CH}_{4}\right)$, and propose improvements to the models, if necessary. The results were compared with the monitored production $\left(\mathrm{P}_{\text {actual }}\right)$ in a farm with CLB using the t-test $(\alpha=5 \%)$. The ChenHashimoto, IPCC, Deng, and modified Stover-Kincannon models showed no statistical difference compared to $\mathrm{P}_{\text {actual }}\left(405.0 \mathrm{~m}^{3} \mathrm{CH}_{4} \mathrm{~d}^{-1}\right)$, whereas the CETESB and COD Conversion models presented no statistical difference after the proposed improvements. All models can be considered reliable for estimating volumetric methane production after the adaptations, being relevant tools for diagnosis and decision-making regarding the energy recovery of biogas with CLB operation in pig farms.
\end{abstract}

\section{INTRODUCTION}

Pig farming is an activity of paramount importance for the economic and social development of Brazil, generating employment and income (Nandorf et al., 2021). This activity generates a high volume of effluents, which can be used in energy generation through anaerobic digestion (Freitas et al., 2019; Ramírez-Islas et al., 2020).

Currently, among the anaerobic digestion technologies for animal waste treatment, the covered lagoon biodigester (CLB), called among Brazilian producers as "Canadian biodigester", is the most used in Brazil (Fernandes Filho et al., 2018), recognized for its ease of installation and lower investment cost compared to other systems. However, the understanding of the kinetics and conversion routes and the biological processes evidenced inside covered lagoon biodigesters is still incipient. Thus, there is a demand for validated mathematical models that can be used in the design and performance prediction of biodigesters relative to the treatment efficiency and biogas production (Yang et al., 2016).
Mathematical models are already consolidated in the literature to estimate methane production from the treatment of domestic sewage by UASB (Upflow Anaerobic Sludge Blanket) reactors (Lobato et al., 2012; Rosa et al., 2020). However, methane production estimation in CLB using reliable mathematical models from easily obtainable operational parameters (temperature, organic load, and hydraulic retention time, among others) is still limited. Chen-Hashimoto (Chen, 1983), CETESB (2006), COD Conversion (Chernicharo, 2016), IPCC (2006), Deng (Deng et al., 2014), and modified Stover-Kincannon (Yu et al., 1998) stand out among the mathematical models used to predict methane production in anaerobic biodigesters. However, several authors have pointed out divergences between the biogas production observed at full scale and that estimated by the models (Bilotta \& Ross, 2016; Camilo, 2017; Coluna, 2016; Mito et al., 2018).

Camilo (2017) observed discrepancies between the estimation of the biogas potential of pig manure and the actual production using the methodologies of Hashimoto et al. (1981) and IPCC (2006). Coluna (2016) found

\footnotetext{
${ }^{1}$ Universidade Federal de Viçosa/ Viçosa - MG, Brasil.
} 
differences in the results of the IPCC and CETESB models, reporting the lack of experiments that allow the comparison of these methodologies and highlighting the attention that must be given to estimates arising from uncertainties, mainly from secondary data obtained in the literature. Mito et al. (2018) evaluated the mathematical models proposed by Chen (1983), IPCC (2006), CIBiogás-ER (2009), and Kunz \& Oliveira (2006) to determine the volumetric methane production in lagoon biodigesters and concluded that the Chen model presented a biogas production value (determined from the theoretical methane production obtained in the models) closer to the actual mean after adapting the coefficients for the Brazilian conditions. However, despite the relevance, the study was limited to the adoption of input data (VS and COD) obtained in the literature.

The use of reliable mathematical models can bring benefits in terms of obtaining quick results, reduction in monitoring costs, improvement in decision-making, evaluation of the system's operational performance, support in inventory studies, increase in energy sustainability, and decentralized energy generation in rural areas (Astals et al., 2013; Majdinasab et al., 2017; Sousa et al., 2020).

However, the parameters adopted in the mathematical models must be evaluated considering the local operational and climate conditions, aiming at a closer approximation of the actual results (Bianek et al., 2018). In Brazil, studies on biogas production, especially using CLB, still have several limitations, such as the use of parameters and coefficients that are not adequate to the local reality or climate conditions, often obtained from laboratory tests. Another limitation in the use of mathematical models is related to the inconsistency of the input data, which are rarely monitored for a long period in full-scale systems. Moreover, model improvement can provide higher precision and reliability to the results.

This study aimed to evaluate, compare, and propose improvements in mathematical models used to estimate the biogas production in full-scale covered lagoon biodigesters (CLB) treating pig manure.

\section{MATERIAL AND METHODS}

An extensive literature review of the main methodologies employed in anaerobic effluent treatment systems was carried out to estimate methane production in CLB from the treatment of pig manure.

The Chen-Hashimoto (Chen, 1983), CETESB (2006), COD Conversion (Chernicharo, 2016), IPCC (2006), Deng (Deng et al., 2014), and modified StoverKincannon (Yu et al., 1998) were selected for this study. Figure 1 shows a flowchart indicating the steps of the study.

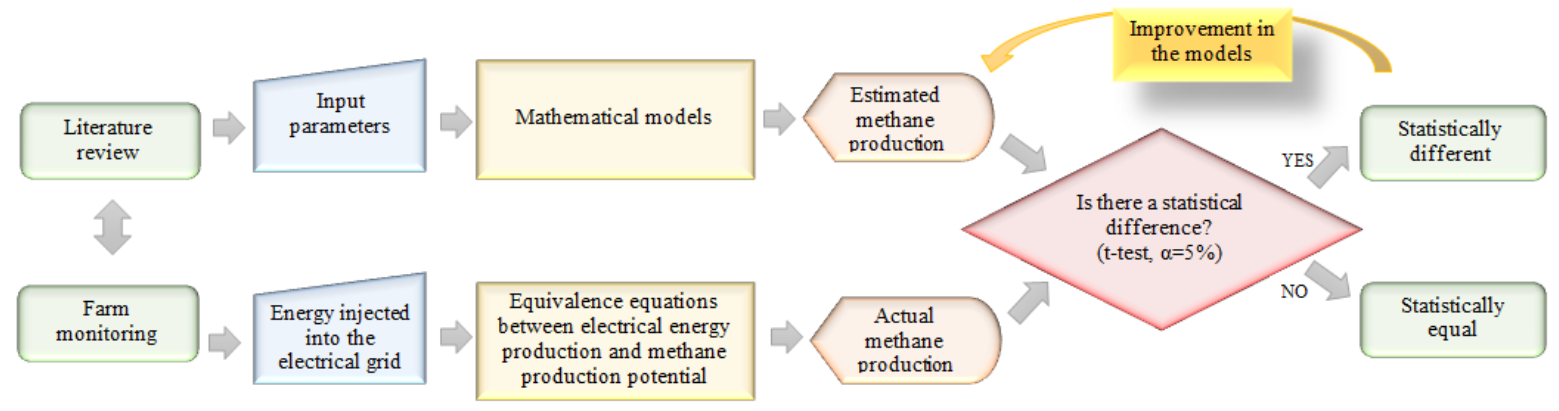

FIGURE 1. Flowchart with the methodological steps of the study.

\section{Characterization of the study area}

Methane production from anaerobic digestion of pig effluents in CLB was determined from the monitoring of a pig farm in the municipality of Teixeiras, located in the Zona da Mata region of Minas Gerais (Brazil). The farm operates in a complete cycle, which covers all stages of production from nursery to finishing, with a total number of animals ranging from 10,280 to 12,519 animals. The biogas produced in the biodigesters is converted into electrical energy in a GMWM120 $120 \mathrm{kVA}$ power motor- generator and injected into the electrical grid of the power utility company.

\section{Biodigester monitoring}

The monitoring of the treatment system was carried out from September 2018 to August 2019 in terms of internal temperature of CLB (resident liquid), volatile solids (VS), chemical oxygen demand (COD), and percentage of methane in the biogas. Figure 2 shows a scheme of the treatment system, with effluent collection points and temperature sensors. 


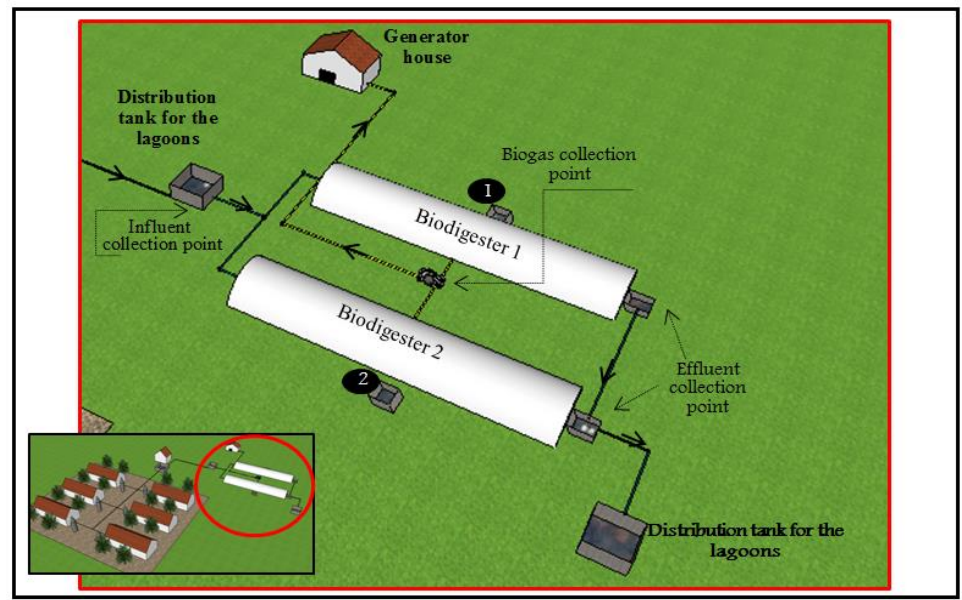

Points 1 and 2 -resident liquid sensors.

FIGURE 2. Schematic representation of the treatment system in a pig farm.

The data collected from temperature sensors are connected to a datalogger, which sends the data continuously to a platform via telemetry, where they are made available and stored.

The quantification of the number of pigs for the study period was informed by the farmers. The effluent flow rate was estimated based on the monthly water consumption measured by hydrometers installed on the farm, considering a return coefficient of 0.65 , in accordance with the recommendation of Souza et al. (2016) for complete-cycle pig systems. The hydraulic retention time (HRT) of CLB was determined from the effluent flow rate and the digester volume $\left(1,250 \mathrm{~m}^{3}\right)$.

Sample collection at the entrance and exit of CLB was carried out weekly at points in the influent that feeds the two biodigesters and the effluent collected at the exit of each biodigester. COD and volatile solids analyses were performed according to APHA (2017). The determination of methane composition in the biogas was carried out from weekly biogas collections, with analyzes were carried out in a gas analyzer (Online Infrared Gas Analyzer, model Gasboard, No. 3100).

\section{Actual volumetric methane production}

The daily volumetric methane production observed on the farm was used as comparative data in the evaluation of the studied models. For this purpose, an equivalence between the electrical energy generated in the motorgenerator system and methane production was used, according to adaptations in the equations presented by Zilotti (2012). The electrical energy generated from biogas (E) and injected into the grid, obtained from the utility's energy bills, was used to calculate the available electric power $(\mathrm{P})$.

$$
T M P=\frac{P}{L C P_{a} \times E f \times \%} \times 24
$$

in which:

TMP is the total methane production $\left(\mathrm{m}^{3} \mathrm{CH}_{4} \mathrm{~d}^{-1}\right)$;

$\mathrm{P}$ is the available electric power $(\mathrm{kW})$;

$\mathrm{LCP}_{\mathrm{a}}$ is the lower available calorific potential $\left(\mathrm{kWh} \mathrm{m}^{-3}\right)$;

Ef is the overall efficiency of thermal machines (0.25);

$\%$ is the percentage of methane in the biogas, and

24 is the conversion factor $\left(\mathrm{h} \mathrm{d}^{-1}\right)$.

$$
P=\frac{E}{m \times 24}
$$

in which:

$\mathrm{E}$ is the total electrical energy generated by the biogas $\left(\mathrm{kWh}\right.$ month $\left.^{-1}\right)$;

$\mathrm{m}$ is the number of days in the month, and

24 is the number of hours in a day (continuous motor-generator).

$$
L C P_{a}=S W \times L C P \times \frac{4.19}{3600}
$$

Where:

SW is the specific weight $\left(\mathrm{kg} \mathrm{Nm}^{-3}\right)$;

LCP is the lower calorific potential $\left(\mathrm{kcal} \mathrm{kg}^{-1}\right)$, and

$4.19 / 3600$ is the conversion constant from kcal into kWh.

\section{Mathematical models}

Table 1 shows an overall characterization of the evaluated mathematical models, as well as a description of the conditions under which they were conceived. 
TABLE 1. Characterization of the selected mathematical models.

\begin{tabular}{|c|c|c|c|c|c|c|}
\hline & $\begin{array}{c}\text { Chen- } \\
\text { Hashimoto } \\
\text { (Chen, 1983) }\end{array}$ & $\begin{array}{c}\text { COD } \\
\text { Conversion } \\
\text { (Chernicharo, } \\
\text { 2016) } \\
\end{array}$ & $\begin{array}{c}\text { CETESB } \\
(2006)\end{array}$ & $\begin{array}{l}\text { IPCC } \\
(2006)\end{array}$ & $\begin{array}{c}\text { Deng } \\
\text { (Deng et al., } \\
\text { 2014) }\end{array}$ & $\begin{array}{c}\text { Modified Stover- } \\
\text { Kincannon } \\
\text { (Yu et al., 1998) }\end{array}$ \\
\hline $\begin{array}{l}\text { Mathematical } \\
\text { principle }\end{array}$ & Kinetic & Mass balance & $\begin{array}{c}\text { Conversion of } \\
\text { consumed energy }\end{array}$ & $\begin{array}{l}\text { Conversion of } \\
\text { consumed energy }\end{array}$ & Kinetic & Kinetic \\
\hline Effluent source & Pigs & $\begin{array}{l}\text { Domestic } \\
\text { sewage }\end{array}$ & $\begin{array}{l}\text { Pigs, cattle, horses, } \\
\text { poultry, and urban } \\
\text { sewage }\end{array}$ & $\begin{array}{l}\text { Pigs, buffalo, and } \\
\text { cattle }\end{array}$ & Pigs & $\begin{array}{c}\text { Soybean } \\
\text { wastewater }\end{array}$ \\
\hline Reactor & $\begin{array}{l}\text { Anaerobic } \\
\text { biodigester }\end{array}$ & UASB & - & - & $\begin{array}{c}\text { Anaerobic } \\
\text { sequencing } \\
\text { batch digester }\end{array}$ & Anaerobic filter \\
\hline Temperature & $30-60{ }^{\circ} \mathrm{C}$ & $\geq 15^{\circ} \mathrm{C}$ & - & $\begin{array}{c}10-28{ }^{\circ} \mathrm{C} \text { (average } \\
\text { annual room } \\
\text { temperature) }\end{array}$ & $15-35^{\circ} \mathrm{C}$ & $34-36{ }^{\circ} \mathrm{C}$ \\
\hline $\begin{array}{l}\text { Organic } \\
\text { concentration }\end{array}$ & $\begin{array}{c}13-65 \mathrm{~kg} \mathrm{VS} \\
\mathrm{m}^{-3}\end{array}$ & - & - & - & - & $\begin{array}{l}4.60-9.27 \mathrm{~kg} \\
\mathrm{COD} \mathrm{m}{ }^{-3}\end{array}$ \\
\hline Loading & - & $\begin{array}{c}2.5-3.5 \mathrm{~kg} \\
\mathrm{COD} \mathrm{m}^{-3} \mathrm{~d}^{-1}\end{array}$ & - & - & $\begin{array}{c}1.21-3.87 \mathrm{~kg} \text { TS } \\
\mathrm{m}^{-3} \mathrm{~d}^{-1}\end{array}$ & $\begin{array}{l}4.41-22.25 \mathrm{~kg} \\
\operatorname{COD~m}{ }^{-3} \mathrm{~d}^{-1}\end{array}$ \\
\hline Methane yield & $\begin{array}{c}0.32-0.52 \mathrm{~m}^{-3} \\
\mathrm{CH}_{4} \mathrm{~kg}^{-1} \mathrm{VS}\end{array}$ & - & - & $\begin{array}{c}0.29-0.48 \mathrm{~m}^{3} \mathrm{CH}_{4} \\
\mathrm{~kg}^{-1} \mathrm{VS} \text { (variable } \\
\text { with country or } \\
\text { region) }\end{array}$ & - & - \\
\hline Solid production & - & $\begin{array}{c}0.11-0.23 \mathrm{~kg} \\
\mathrm{COD}_{\text {sludge }} \mathrm{kg}^{-1} \\
\mathrm{COD}_{\text {applied }}\end{array}$ & - & - & - & - \\
\hline Design/applicability & $\begin{array}{l}\text { Laboratory and } \\
\text { pilot } \\
\text { experiment }\end{array}$ & $\begin{array}{l}\text { Pilot and full } \\
\text { scale }\end{array}$ & $\begin{array}{c}\text { Inventory of } \mathrm{CH}_{4} \\
\text { emissions generated } \\
\text { by anaerobic waste } \\
\text { degradation in Brazil }\end{array}$ & $\begin{array}{c}\text { Inventory of } \mathrm{CH}_{4} \\
\text { emissions generated } \\
\text { by anaerobic waste } \\
\text { degradation }\end{array}$ & $\begin{array}{l}\text { Laboratory } \\
\text { experiment }\end{array}$ & $\begin{array}{c}\text { Laboratory, pilot, } \\
\text { and full-scale } \\
\text { experiment }\end{array}$ \\
\hline
\end{tabular}

HRT: Hydraulic retention time; UASB: Upflow anaerobic sludge blanket.

The selected mathematical models were standardized in terms of volumetric methane production (Equations 4-19). The input data of the models were obtained from the monitoring of the number of animals, effluent flow rate, inlet and outlet concentration of COD and VS, resident liquid temperature, and methane composition. The coefficient data and other model parameters were adopted based on the original methodologies. The model evaluation was carried out in terms of the comparison of the monthly mean volumetric methane production of the five proposed methodologies, with the actual data obtained on the farm $\left(\mathrm{P}_{\text {actual }}\right)$ and determined from electrical energy production and its conversion into equivalent methane production values.

\section{Chen-Hashimoto model (Chen, 1983)}

$$
B=B_{0} x\left(1-\frac{K}{\mu m H R T-1+K}\right)
$$

Where:

$\mathrm{B}$ is the methane production $\left(\mathrm{m}^{3} \mathrm{CH}_{4} \mathrm{~kg}^{-1} \mathrm{VS}\right)$;

$\mathrm{B}_{0}$ is the methane yield $\left(0.36 \mathrm{~m}^{3} \mathrm{CH}_{4} \mathrm{~kg}^{-1} \mathrm{VS}\right)$ (Chae et al., 2008);

$\mu \mathrm{m}$ is the maximum specific microorganism growth $\left(\mathrm{d}^{-1}\right)$;

HRT is the hydraulic retention time (d), and

$\mathrm{K}$ is the kinetic constant.
$K=0.6+0.0006 e^{(0.1185 x V S)}$

Where:

VS is the volatile solids content in the influent $(\mathrm{kg}$ $\mathrm{VS} \mathrm{m}^{-3}$ ).

$$
\mu m=0.013 T-0.129
$$

Where:

$\mathrm{T}$ is the resident liquid temperature $\left({ }^{\circ} \mathrm{C}\right)$.

$$
Q_{C_{4}}=B x Q_{e f f l} \times V S
$$

in which:

$Q_{\text {effl }}$ is the effluent flow rate $\left(\mathrm{m}^{3} \mathrm{~d}^{-1}\right)$, and

$\mathrm{Q}_{\mathrm{CH} 4}$ is the methane production $\left(\mathrm{m}^{3} \mathrm{CH}_{4} \mathrm{~d}^{-1}\right)$.

COD Conversion model (Chernicharo, 2016)

$$
C O D_{C_{4}}=Q_{e f f l} x\left(S_{0}-S\right)-Y_{o b s} \times Q_{e f f l} \times S_{0}
$$

Where:

$\mathrm{COD}_{\mathrm{CH} 4}$ is the COD load converted into methane $(\mathrm{kg}$ $\left.\mathrm{COD}_{\mathrm{CH} 4} \mathrm{~d}^{-1}\right)$;

$\mathrm{S}_{0}$ is the influent COD $\left(\mathrm{kg} \mathrm{m}^{-3}\right)$;

$\mathrm{S}$ is the COD effluent $\left(\mathrm{kg} \mathrm{m}^{-3}\right)$; 
$Q_{\text {effl }}$ is the effluent flow rate $\left(\mathrm{m}^{3} \mathrm{~d}^{-1}\right)$, and

$Y_{\text {obs }}$ is the solids production coefficient $(0.19 \mathrm{~kg}$ $\mathrm{COD}_{\text {sludge }} \mathrm{kg}^{-1} \mathrm{COD}$ ).

$$
f(T)=\frac{P \times K_{C O D}}{R \times(273+T)}
$$

in which:

$f(\mathrm{~T})$ is the correction factor for the reactor temperature $\left(\mathrm{kg} \mathrm{COD} \mathrm{m}^{-3}\right)$;

$\mathrm{P}$ is the atmospheric pressure (0.92 atm);

$\mathrm{K}_{\mathrm{COD}}$ is the COD corresponding to one mol of $\mathrm{CH}_{4}$ $\left(64 \mathrm{~g} \mathrm{COD} \mathrm{mol}^{-1}\right)$;

$\mathrm{R}$ is the gas constant $\left(0.08206 \mathrm{~atm} \mathrm{~L} \mathrm{~mol}^{-1} \mathrm{~K}\right)$, and

$\mathrm{T}$ is the resident liquid temperature $\left({ }^{\circ} \mathrm{C}\right)$.

$$
Q_{C H_{4}}=\frac{C^{C O D} H_{4}}{f(T)}
$$

\section{CETESB model (2006)}

$$
Q_{\mathrm{CH}_{4}}=\frac{1}{V S} \times\left(\mathrm{Pb} \times \mathrm{N} \times \mathrm{Mt} \times \mathrm{CH}_{4} \%\right)
$$

Where:

VS is the specific volume of methane $\left(0.67 \mathrm{~kg} \mathrm{CH}_{4}\right.$ $\mathrm{m}^{-3} \mathrm{CH}_{4}$ );

$\mathrm{Pb}$ is the biogas production ( $0.062 \mathrm{~kg}$ biogas $\mathrm{kg}^{-1} \mathrm{M}_{\mathrm{t}}$ );

$\mathrm{N}$ is the total number of animals;

$\mathrm{M}_{\mathrm{t}}$ is the matter produced per animal $\left(2.25 \mathrm{~kg} \mathrm{M}_{\mathrm{t}} \mathrm{d}^{-1}\right.$ animal $^{-1}$ ), and

$\mathrm{CH}_{4} \%$ is the percentage of methane in the biogas (\%).

\section{IPCC model (2006)}

$$
Q_{C H_{4}}=N \times\left[V S \times B_{0} \times \frac{M C F}{100} \times M S\right]
$$

in which:

VS is the volatile solids $(0.3 \mathrm{~kg}$ of dry matter animal $^{-1} \mathrm{~d}^{-1}$ );

$\mathrm{B}_{\mathrm{o}}$ is the methane yield $\left(0.29 \mathrm{~m}^{3} \mathrm{CH}_{4} \mathrm{~kg}^{-1} \mathrm{VS}\right)$;

$\mathrm{MCF}$ represents the methane conversion factors for each manure management system $\mathrm{S}$ by climate region $\mathrm{k}(79 \%)$;

MS is the fraction of animal manure with manure management system $\mathrm{S}$ in climate region $\mathrm{k}(1)$, and

$\mathrm{N}$ is the total number of animals.

\section{Deng model (Deng et al., 2014)}

$$
R_{p}=\frac{R_{p \max }}{1+e^{\left(K_{L R}-L r\right)}}
$$

Where:

$\mathrm{Rp}$ is the volumetric methane production rate $\left(\mathrm{m}^{3}\right.$ $\left.\mathrm{CH}_{4} \mathrm{~m}^{-3} \mathrm{~d}^{-1}\right)$;
$\mathrm{R}_{\text {pmax }}$ is the maximum volumetric methane production rate $\left(\mathrm{m}^{3} \mathrm{CH}_{4} \mathrm{~m}^{-3} \mathrm{~d}^{-1}\right)^{2}$;

$\mathrm{K}_{\mathrm{LR}}$ is the half-saturation constant $\left(\mathrm{kg} \mathrm{VS} \mathrm{m}^{-3} \mathrm{~d}^{-1}\right)^{2}$, and $\mathrm{Lr}$ is the volumetric organic loading $\left(\mathrm{kg} \mathrm{VS} \mathrm{m}^{-3} \mathrm{~d}^{-1}\right)$.

$$
\begin{aligned}
& R_{\text {pmax }}=2.760-7.181 e^{(0.067 T)} \\
& K_{L R}=3.469-13.676 e^{(-0.101 T)} \\
& L r=\frac{V S x Q_{\text {effl }}}{V}
\end{aligned}
$$

Where:

$\mathrm{V}$ is the digester volume $\left(\mathrm{m}^{3}\right)^{2}$.

$$
Q_{C_{4}}=R_{p} x Q_{e f f l}
$$

Modified Stover-Kincannon model (Yu et al., 1998)

$$
M=\frac{M_{\text {max }} \times Q_{e f f l} \times \frac{V S}{V}}{M_{B} \times Q_{e f f l} \times \frac{V S}{V}}
$$

in which:

$M$ is specific methane production $\left(\mathrm{m}^{3} \mathrm{~m}^{-3} \mathrm{~d}^{-1}\right)$;

$\mathrm{M}_{\max }$ is the maximum specific methane production $\left(19.23 \mathrm{~m}^{3} \mathrm{~m}^{-3} \mathrm{~d}^{-1}\right)$;

$\mathrm{M}_{\mathrm{B}}$ is a constant $\left(53.46 \mathrm{~kg} \mathrm{~m}^{-3} \mathrm{~d}^{-c}\right)$;

$\mathrm{Q}_{\text {effl }}$ is the effluent flow rate $\left(\mathrm{m}^{3} \mathrm{~d}^{-1}\right)$;

VS is the concentration of volatile solids in the influent $\left(\mathrm{kg} \mathrm{VS} \mathrm{m}^{-3}\right)$, and

$\mathrm{V}$ is the digester volume.

$$
Q_{\mathrm{CH}_{4}}=M \times \mathrm{V}
$$

Model comparison in terms of methane production was performed utilizing simple linear regression passing through the origin and tested by the Student's t-test at a 5\% probability level. The BIAS statistical coefficient (mean error) was used as a performance indicator of the models to evaluate the model accuracy. The coefficient provides an idea of the model trend (systematic error) to predict actual observed values, and values closer to zero indicated a good simulation (Xavier et al., 2016).

Moreover, the study was carried out for hot (October 2018 to March 2019) and cold periods (September 2018 and April 2019 to August 2019) in terms of statistical difference regarding the methane production associated with seasonal climate variations.

\section{RESULTS AND DISCUSSION}

\section{Monitoring of biodigesters and model input data}

Figure 3 shows the time series of the number of animals and the effluent flow rate. Large variations in the number of animals and effluent flow rate were not observed, with 10,793 animals and $101.2 \mathrm{~m}^{3} \mathrm{~d}^{-1}$ in the cold period and 10,884 animals and $103.2 \mathrm{~m}^{3} \mathrm{~d}^{-1}$ in the hot period, respectively.

${ }^{2} R_{\mathrm{pmax}}$ and $\mathrm{K}_{\mathrm{LR}}$ were determined by equations of Yang et al. (2016). 


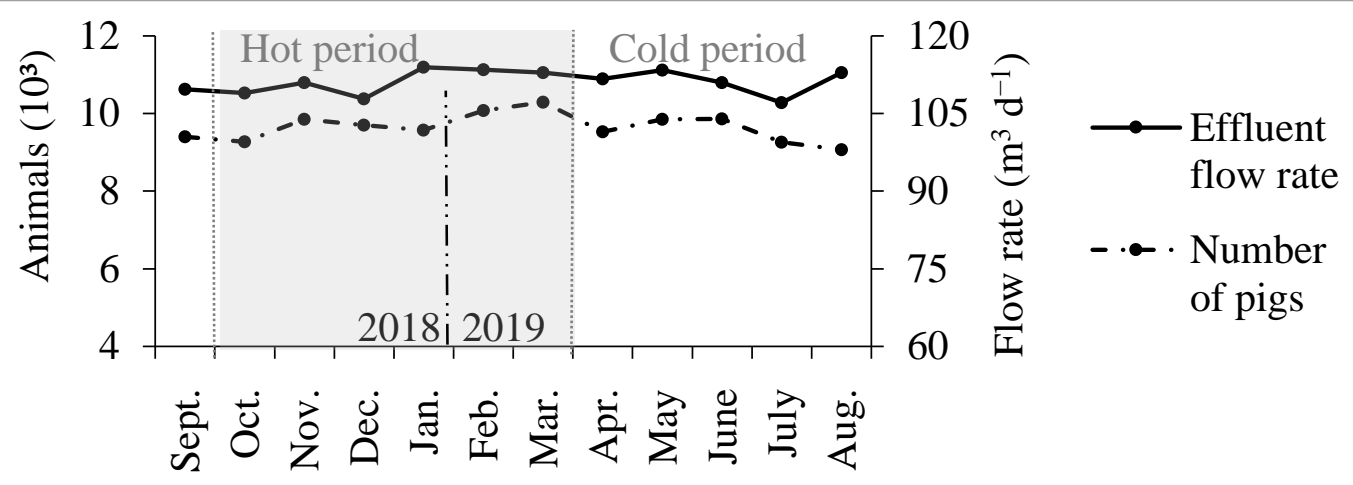

FIGURE 3. Monthly mean number of animals and effluent flow rate (September 2018 to August 2019).

Figure 4 shows the monitoring of effluent quality. In general, influent VS concentrations followed the changes in COD at the system input.

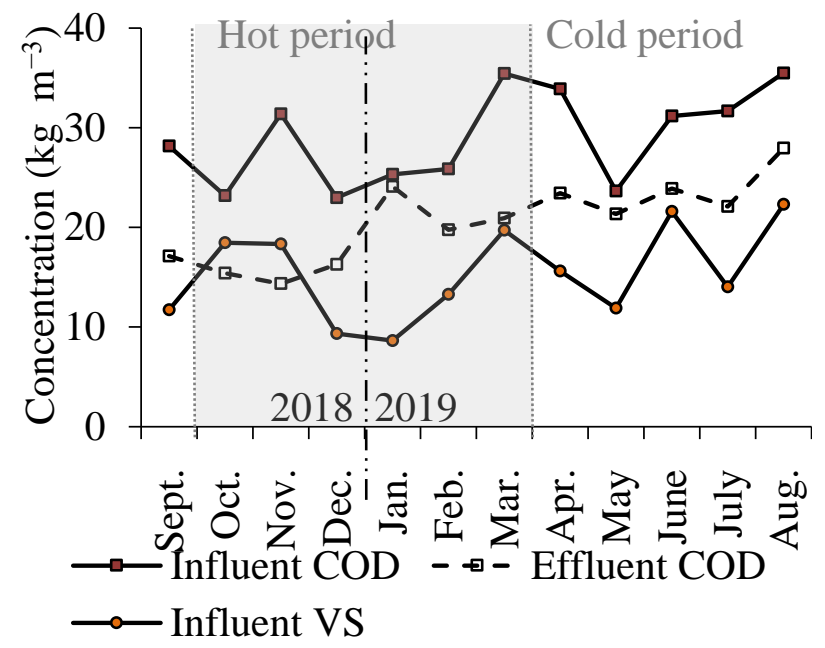

FIGURE 4. Monthly mean COD and volatile solids (VS).

Figure 5 shows the methane content and the mean temperature of the resident liquid inside the CLB. The mean temperature was $23.9^{\circ} \mathrm{C}$ in the hot period and $21.7^{\circ} \mathrm{C}$ in the cold period, with a mean of $22.8^{\circ} \mathrm{C}$ for the entire period. The percentage of methane $\left(\mathrm{CH}_{4}\right)$ in the biogas showed a wide variation (43.6-81.9\%), following a more evident decreasing trend with the beginning of the cold period, which was observed with less intensity for the resident liquid temperature.

Variations in COD and VS concentrations are mainly due to variations in the farm management, influenced by the routine of washing the stalls, which can lead to manure dilutions. Hydraulic retention time, $\mathrm{pH}$, and alkalinity can affect anaerobic biodigestion and, consequently, influence the percentage of methane in the biogas (Ferreira et al., 2017).

No linear correlation was observed between the percentage of biogas and resident liquid temperature at a $5 \%$

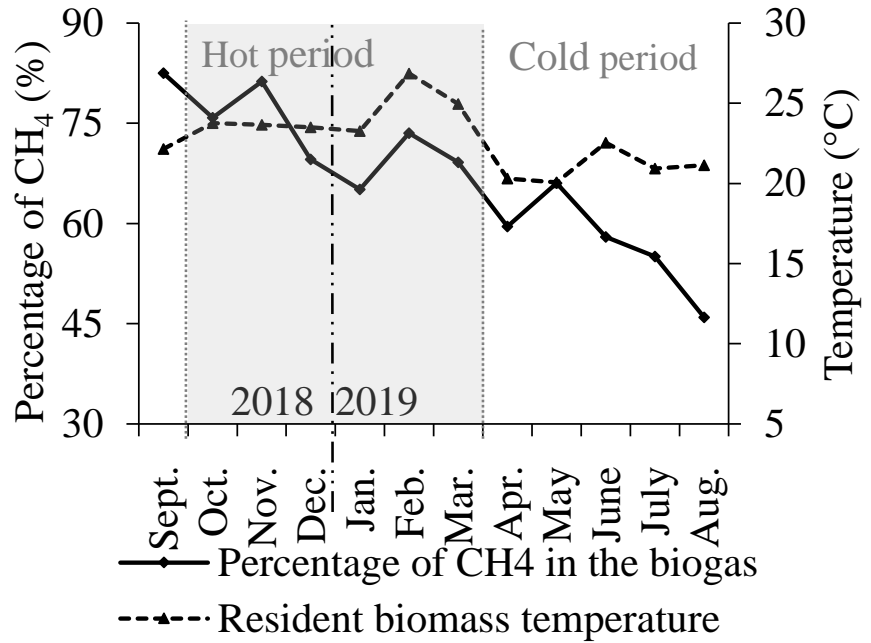

FIGURE 5. Monthly mean of the percentage of $\mathrm{CH}_{4}$ and resident liquid temperature.

significance level in both periods ( $\mathrm{p}$-value equal to 0,0718 in the annual period, 0.9423 in the hot period, and 0.4240 in the cold period). Similarly, no significant linear correlation was found between COD removal efficiency and resident liquid temperature (p-value equal to 0.4437 in the annual period, 0.9965 in the hot period, and 0.3779 in the cold period), as well as between COD removal efficiency and the percentage of methane ( $p$-value equal to 0.1618 in the annual period, 0.1743 in the hot period, and 0.4470 in the cold period).

\section{Methane production estimation and comparison of models}

Figure 6 shows the time series of methane and biogas production obtained through the evaluated models and $\mathrm{P}_{\text {actual. }}$ 


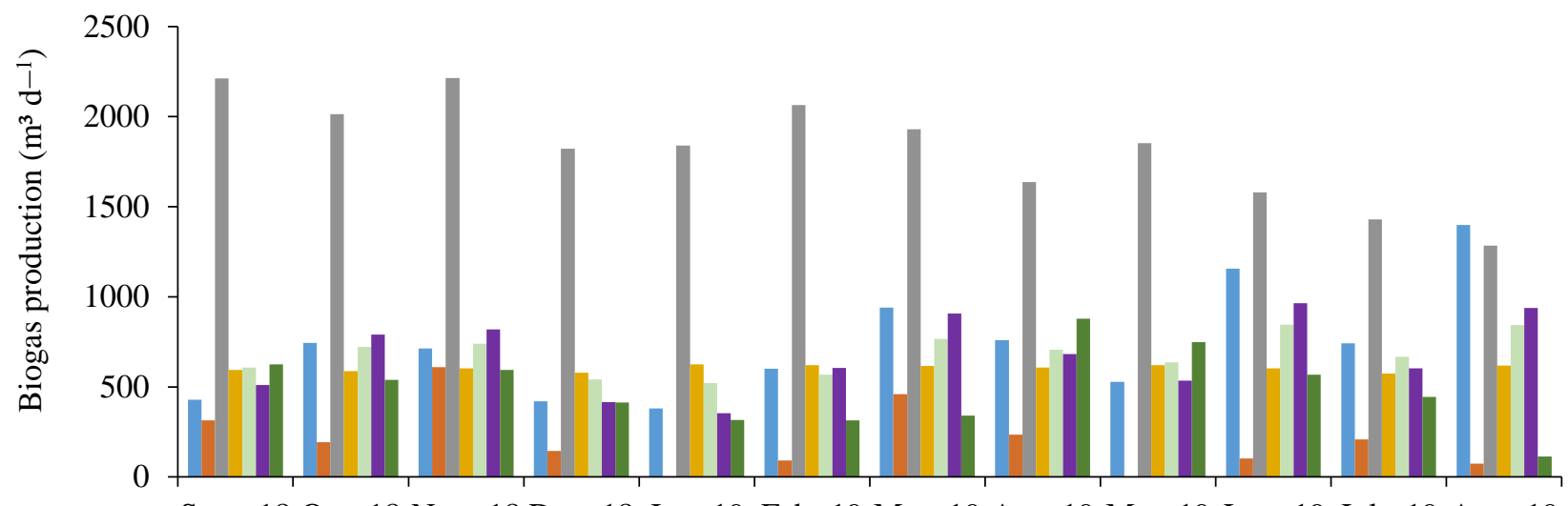

Sept.-18 Oct.-18 Nov.-18 Dec.-18 Jan.-19 Feb.-19 Mar.-19 Apr.-19 May-19 June-19 July-19 Aug.-19

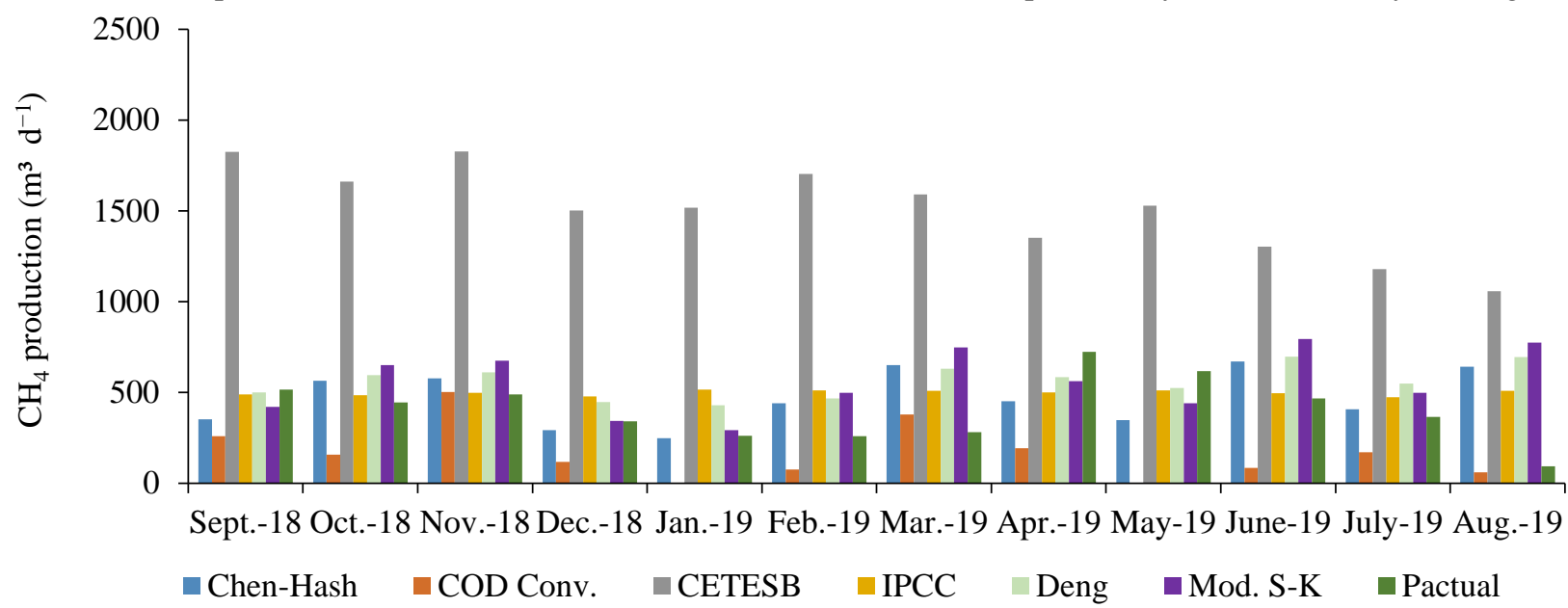

Chen-Hash: Chen-Hashimoto (Chen, 1983); COD Conv.: COD Conversion (Chernicharo, 2016), CETESB: CETESB (2006), IPCC: IPCC (2006), Deng: Deng (Deng et al., 2014); Mod S-K: modified Stover-Kincannon (Yu et al., 1998).

FIGURE 6. Biogas and $\mathrm{CH}_{4}$ production for the evaluated models and production observed on the farm $\left(\mathrm{P}_{\text {actual }}\right)$.

The CETESB and COD concentration model presented the most discrepant results in comparison with $\mathrm{P}_{\text {actual. }}$ The IPCC model, although presenting a mean close to the mean $\mathrm{P}_{\text {actual }}$, did not represent variations in the methane and biogas production observed on the farm, which may refer the success of the model to a specific case. However, the mean values of the Chen-Hashimoto (Chen, 1983), IPCC (2006), Deng (Deng et al., 2014), and modified
Stover-Kincannon (Yu et al., 1998) models did not differ statistically from $\mathrm{P}_{\text {actual, }}$ while the original CETESB and COD Conversion models differed statistically from the farm production at the $5 \%$ probability level (Table 2 ). The ChenHashimoto model showed the best qualitative performance regarding the performance indicator, with an overestimation of $65.9 \mathrm{~m}^{3} \mathrm{CH}_{4} \mathrm{~d}^{-1}$.

TABLE 2. Statistical analysis of the monthly methane $\left(\mathrm{CH}_{4}\right)$ production obtained through mathematical models in comparison with the production observed on the farm $\left(\mathrm{P}_{\text {actual }}\right)$.

\begin{tabular}{ccccccc}
\hline & $\begin{array}{c}\text { Chen- } \\
\text { Hashimoto } \\
(\text { Chen, 1983) }\end{array}$ & $\begin{array}{c}\text { COD Conversion } \\
\text { (Chernicharo, } \\
2016)\end{array}$ & $\begin{array}{c}\text { CETESB } \\
(2006)\end{array}$ & $\begin{array}{c}\text { IPCC } \\
(2006)\end{array}$ & $\begin{array}{c}\text { Deng } \\
\text { (Deng et al., } \\
2014)\end{array}$ & $\begin{array}{c}\text { Modified Stover- } \\
\text { Kincannon } \\
(\text { Yu et al., 1998) }\end{array}$ \\
\hline Mean $\left(\mathrm{m}^{3} \mathrm{CH}_{4} \mathrm{~d}^{-1}\right)$ & 470.8 & 166.7 & 1504.2 & 498.2 & 560.9 & 558.6 \\
$\mathbf{t}_{\text {calc }}$ & $-0.1^{\mathrm{ns}}$ & $-6.2^{*}$ & $5.8^{*}$ & $0.4^{\mathrm{ns}}$ & $1.2^{\mathrm{ns}}$ & $-1.7^{\mathrm{ns}}$ \\
BIAS $\left(\mathrm{m}^{3} \mathrm{~d}^{-1}\right)$ & 65.9 & -238.3 & 1099.2 & 93.2 & 156.0 & 153.3 \\
\hline
\end{tabular}

t-test $-\mathrm{H}_{0}: \beta_{1}=1\left(\mu_{\text {model }}=\mu\right.$ Pactual $)$ and $\mathrm{H}_{1}: \beta 1 \neq 1\left(\mu_{\text {model }} \neq \mu\right.$ Pactual $) ; *$ : Means differ from each other at the $5 \%$ probability level; ${ }^{\text {ns: }}$ Means do not differ statistically from each other; $\mathrm{t}_{\text {tab } 5 \%(11)} 2.26$.

The models can be used regardless of seasonal variations, as the estimated values of volumetric methane production of all models do not present a significant difference at the 5\% probability when comparing the hot and cold periods (Table 3 ). 
TABLE 3. Statistical analysis of the monthly methane $\left(\mathrm{CH}_{4}\right)$ production obtained through mathematical models in the hot period compared to the cold period.

\begin{tabular}{ccccccc}
\hline & $\begin{array}{c}\text { Chen- } \\
\text { Hashimoto } \\
(\text { Chen, 1983) }\end{array}$ & $\begin{array}{c}\text { COD Conversion } \\
\text { (Chernicharo, } \\
2016)\end{array}$ & $\begin{array}{c}\text { CETESB } \\
(2006)\end{array}$ & $\begin{array}{c}\text { IPCC } \\
(2006)\end{array}$ & $\begin{array}{c}\text { Deng } \\
\text { (Deng et al., } \\
2014)\end{array}$ & $\begin{array}{c}\text { Modified Stover- } \\
\text { Kincannon } \\
(\text { Yu et al., 1998) }\end{array}$ \\
\hline $\mathbf{t}_{\text {calc }}$ & $-0.6^{\mathrm{ns}}$ & $0.4^{\mathrm{ns}}$ & $1.5^{\mathrm{ns}}$ & $0.2^{\mathrm{ns}}$ & $-1.5^{\mathrm{ns}}$ & $-0.9^{\mathrm{ns}}$ \\
\hline
\end{tabular}

t-test $-\mathrm{H}_{0}: \beta_{1}=1\left(\mu_{\text {model }}=\mu\right.$ Pactual $)$ and $\mathrm{H}_{1}: \beta 1 \neq 1\left(\mu_{\text {model }} \neq \mu_{\text {Pactual }}\right)$; *: Means differ from each other at the $5 \%$ probability level; ${ }^{\text {ns: }}$ Means do not differ statistically from each other; $\mathrm{t}_{\text {tab } 5 \%(11)} 2.26$.

The mean $P_{\text {actual }}$ value for the evaluated period was $405.0 \mathrm{~m}^{3} \mathrm{CH}_{4} \mathrm{~d}^{-1}$. The Chen-Hashimoto model indicated a mean production of $470.8 \mathrm{~m}^{3} \mathrm{CH}_{4} \mathrm{~d}^{-1}$. This mathematical model is one of the most used and provides reliability in predicting methane production (Kafle \& Chen, 2016; Li et al., 2019). The Chen-Hashimoto model presented a mean value close to $\mathrm{P}_{\text {actual }}$ although initially recommended for a temperature range between 30 and $60^{\circ} \mathrm{C}$.

The COD Conversion model resulted in a mean production of $166.7 \mathrm{~m}^{3} \mathrm{CH}_{4} \mathrm{~d}^{-1}$. This model, which was conceived based on the study of matter conversion routes in terms of COD, presents some limitations that may have compromised methane production estimation, namely: (i) flow rate fluctuation; (ii) variation in influent COD; (iii) quantification of sludge production; and (iv) methane losses due to leakage and the dissolved form in the effluent (Lobato et al., 2012). Souza et al. (2011) evaluated the mass balance in pilot-scale UASB reactors and identified that COD loss in the system in terms of methane dissolved in the effluent reached $41 \%$ of the COD applied in the system. Further studies of organic matter conversion routes in CLB biodigesters must be carried out to quantify and consider the portions involved in the mass balance.

The methodology proposed by CETESB (2006) is characterized by its simplicity, as the main input variable of the model is the number of animals. The mean value for the study was $1,504.2 \mathrm{~m}^{3} \mathrm{CH}_{4} \mathrm{~d}^{-1}$. The biogas conversion coefficient suggested in the CETESB (2006) methodology is $0.062 \mathrm{~kg}$ biogas kg-1 manure, which is a usual unitary ratio for estimating biogas production (Coluna, 2016; Santos \& Nardir Junior, 2013). However, this coefficient does not consider other factors that directly influence biogas production in biodigesters, such as temperature and HRT. Furthermore, this model is not sensitive to variations in the effluent load in terms of organic matter and solids and as well as in the removal efficiency of these constituents, which are associated with effluent degradability.

The IPCC model also considers the number of animals as the main model input. The mean production value was $498.2 \mathrm{~m}^{3} \mathrm{CH}_{4} \mathrm{~d}^{-1}$ and did not differ statistically from the $P_{\text {actual }}$ value (Figure 6). However, it presented less variation over the monitored period, not being considered sensitive to fluctuations in the effluent and CLB operation. Coluna (2016) compared the IPCC and CETESB models and also identified divergences between their estimations.

Mito et al. (2018) evaluated and compared the IPCC, CIBiogás-ER, Chen, and Kunz mathematical models and pointed out that the Chen-Hashimoto model (Chen, 1983) showed the worst performance. However, input data such as the content of volatile solids and effluent flow were obtained from the literature.

Yang et al. (2016) compared the $\mathrm{CH}_{4}$ production between the Chen-Hashimoto and Deng and StoverKincannon models in sequential batch reactors at a laboratory scale using pig manure and also obtained a better fit of the Chen model.

\section{Models improvements}

Improvements were proposed for the COD Conversion and CETESB mathematical models, which differed statistically, to provide higher reliability in the estimation of methane production.

The estimation of biogas production by the COD Conversion model uses the solids production coefficient ( $Y_{\text {obs }}$ of $0.19 \mathrm{~kg} \mathrm{COD}_{\text {sludge }} \mathrm{kg}^{-1} \mathrm{COD}$ ), a reference value for domestic sewage. Hydraulic conditions stand out in addition to the difference in the type of effluent, as CLB operates with high HRT. The proposed improvement suggests the calculation of the solids conversion coefficient proposed by Metcalf \& Eddy (2016) (Equation 20), which considers, in addition to kinetic conditions, the HRT influence in the effluent treatment.

Furthermore, another important limitation of the methodology (Equation 8) would be associated with the fact that the organic matter conversion route to the sludge plot $\left(\mathrm{Y}_{\mathrm{obs}} \times \mathrm{Q}_{\text {effl }} \times \mathrm{S}_{0}\right)$ disregards the treatment efficiency, with solids accumulation linked only to input conditions. For this, the equation adequacy is presented in eqs (20) and (21).

$$
Y_{o b s}=\frac{Y_{S}}{1+K_{d} \times H R T}
$$

in which:

$\mathrm{Y}_{\mathrm{obs}}$ is the coefficient of solids production in the system in terms of COD $\left(\mathrm{kg} \mathrm{COD}_{\text {sludge }} \mathrm{g}^{-1}\right.$ CODapplied);

Ys is the coefficient of solids in the system for pig effluents $\left(0.03 \mathrm{~kg}\right.$ COD TVS $\left.\mathrm{kg}^{-1} \mathrm{COD}_{\text {applied }}\right)$ (Rodrigues, 2008);

$K_{d}$ is the endogenous respiration coefficient for pig effluents $\left(0.011 \mathrm{~d}^{-1}\right)$ (Rodrigues, 2008), and

HRT is the hydraulic retention time (d).

$$
\mathrm{COD}_{\mathrm{CH}_{4}}=Q_{\text {effl }} \times\left(S_{0}-S\right)-\text { Yobs } \times Q_{e f f l} \times(\text { So }-S)
$$

Where:

$\mathrm{COD}_{\mathrm{CH} 4}$ is the $\mathrm{COD}$ load converted into methane $(\mathrm{kg}$ $\left.\mathrm{COD}_{\mathrm{CH} 4} \mathrm{~d}^{-1}\right)$,

$\mathrm{S}_{0}$ is the COD concentration in the influent $\left(\mathrm{kg} \mathrm{m}^{-3}\right)$,

$\mathrm{S}$ is the COD concentration in the effluent $\left(\mathrm{kg} \mathrm{m}^{-3}\right)$, and

$Q_{\text {effl }}$ is the effluent flow rate $\left(\mathrm{m}^{3} \mathrm{~d}^{-1}\right)$.

The CETESB model determines $\mathrm{CH}_{4}$ production based on unit relationships obtained in the literature and the 
number of animals. However, the improvement in the model proposes to consider the organic matter conversion routes in the reactor, expressed in terms of COD removal efficiency (Equation 22).

$$
Q_{C H 4}=\frac{1}{V S} \times\left(P b \times E F \% \times N \times M t \times \mathrm{CH}_{4} \%\right)
$$

in which:

$\mathrm{Q}_{\mathrm{CH} 4}$ is the methane production $\left(\mathrm{m}^{3} \mathrm{CH}_{4} \mathrm{~d}^{-1}\right)$;

VS is the specific volume of methane $\left(0.67 \mathrm{~kg} \mathrm{CH}_{4}\right.$ $\mathrm{m}^{-3} \mathrm{CH}_{4}$ );

$\mathrm{Pb}$ is the biogas production $\left(0.062 \mathrm{~kg}\right.$ biogas $\left.\mathrm{kg}^{-1} \mathrm{M}_{\mathrm{t}}\right)$;
$\mathrm{EF}$ is the COD removal efficiency ${ }^{3}(\%)$;

$\mathrm{N}$ is the total number of animals;

$\mathrm{M}_{\mathrm{t}}$ is the matter produced per animal $\left(2.25 \mathrm{~kg} \mathrm{M}_{\mathrm{t}} \mathrm{d}^{-1}\right.$ animal $^{-1}$ ), and

$\mathrm{CH}_{4}$ is the percentage of methane in the biogas (\%).

The results of the statistical analysis for the improved mathematical models compared to the production obtained on the monitored farm are shown in Table 4, considering the $\mathrm{P}_{\text {actual }}$ value of $405.0 \mathrm{~m}^{3} \mathrm{~d}^{-1}$.

TABLE 4. Statistical analysis of methane production $\left(\mathrm{CH}_{4}\right)$ obtained using improved mathematical models in comparison with the production observed on the farm $\left(\mathrm{P}_{\text {actual }}\right)$.

\begin{tabular}{lcc}
\hline & COD Conversion & CETESB \\
\hline Original model & & $1,504.2$ \\
\hline Mean $\left(\mathrm{m}^{3} \mathrm{CH}_{4} \mathrm{~d}^{-1}\right)$ & 166.7 & \\
\hline Improved model & & 417.2 \\
\hline Mean $\left(\mathrm{m}^{3} \mathrm{CH}_{4} \mathrm{~d}^{-1}\right)$ & 345.2 & $0.4^{\mathrm{ns}}$ \\
tcalc & $1.7^{\mathrm{ns}}$ & 12.2 \\
BIAS $\left(\mathrm{m}^{3} \mathrm{CH}_{4} \mathrm{~d}^{-1}\right)$ & -59.8 & \\
\hline
\end{tabular}

t-test $-\mathrm{H}_{0}: \beta_{1}=1\left(\mu_{\text {model }}=\mu\right.$ Pactual $)$ and $\mathrm{H}_{1}: \beta 1 \neq 1\left(\mu_{\text {model }} \neq \mu\right.$ Pactual $) ; *$ : Means differ from each other at the $5 \%$ probability level; ${ }^{\text {ns: }}$ Means do not differ statistically from each other; $t_{\text {tab }} \%$ (11) 2.2 .

The COD Conversion and CETESB models showed no statistically significant difference at a $5 \%$ probability level after the improvements compared to the production observed on the farm. Moreover, the improved CETESB model showed BIAS closer to zero $\left(12.2 \mathrm{~m}^{3} \mathrm{CH}_{4} \mathrm{~d}^{-1}\right.$ ) (Table 4 ), which refers to the lowest systematic error compared to the improved COD Conversion model, as well as all other evaluated original models.

Simplified models, such as the CETESB model, have gained attention, given the limited applicability of complex models in the operation and improvement of biodigester plants (Yang et al., 2016). In contrast, the COD conversion model requires better system monitoring.

The improved CETESB model can be used in pig farms to estimate the energy potential of biogas, either on farms already under operation or at the design stage of the energy recovery system. The input data correspond to the number of animals (easy to obtain data), as well as the expected COD removal efficiency and methane composition in the biogas, data that can be obtained from the literature, if necessary.

\section{CONCLUSIONS}

The original Chen-Hashimoto (Chen, 1983), Deng (Deng et al., 2014), and modified Stover-Kincannon (Yu et al., 1998) models were considered reliable to predict volumetric methane production in covered lagoon biodigesters treating pig manure. Among them, the ChenHashimoto model had the best performance.

3 Series with COD removal values $(\%)$ for the period from September 2018 to August $2019(39.2-33.6-54.3-29.1-4.8-$ $23.6-41-30.8-9.7-23.3-30.3-21.3)$.
The improved CETESB (2006) and COD Conversion (Chernicharo, 2016) models also presented no differences for the monitoring and prediction of methane on pig farms, standing out the correction applied to the Chernicharo (2016) formulation, which presented the lowest BIAS among the evaluated models.

The improved IPCC and CETESB models can be characterized by their higher simplicity in terms of input data (number of animals, expected system efficiency, and mean percentage of $\mathrm{CH}_{4}$ in the biogas), which would allow their application in design studies of new systems. On the other hand, the other models require greater knowledge of the operating and monitoring conditions of the system, as they require kinetic and hydraulic conditions, resident fluid temperature, volatile solids content, and COD as input data.

The original Chen-Hashimoto, IPCC, Deng, and modified Stover-Kincannon models, as well as the proposed improvements in the COD Conversion and CETESB models, can be used to estimate methane production in covered lagoon biodigesters.

\section{ACKNOWLEDGMENTS}

This study was partially funded by the Coordination for the Improvement of Higher Education Personnel Brazil (CAPES) - Financing Code 001, the National Council for Scientific and Technological Development Brazil (CNPq), and the Foundation for Research Support of the State of Minas Gerais (FAPEMIG) under the grant number APQ-01109-18. 


\section{REFERENCES}

APHA - American Public Health Association \& American Water Works Association (2017) Standard methods for the examination of water and wastewater. American Public Health Association. Water Environment Federation. Washington. 23 ed.

Astals S, Esteban-Gutiérrez M, Fernández-Arévalo T, Aymerich E, García-Herasb JL, Mata-Alvareza J (2013) Anaerobic digestion of seven different sewage sludges: a biodegradability and modelling study. Water Research 47(16): 6033-6043. DOI: https://doi.org/10.1016/j.watres.2013.07.019.

Bianek J, Schirmer WN, Cabral AR, Mayer CL, Eurich PH, Martins, EH (2018) Comparação entre metodologias USEPA E IPCC para estimativa teórica de produção de biogás em aterro municipal. BIOFIX Scientific Journal 3(1): 34. DOI: https://doi.org/10.5380/biofix.v3i1.56038.

Camilo NC (2017) Suinocultura e o potencial energético do biogás no município de São Miguel do Iguaçu - PR. Magister Scientiae Thesis, Universidade Tecnológica Federal do Paraná.

CETESB - Companhia de Tecnologia de Saneamento Ambiental (2006) Manual do usuário do programa de computador Biogás: geração e uso energético - efluentes e resíduo rural - versão 1.0. Secretaria Do Meio Ambiente, Ministério Da Ciência e Tecnologia, São Paulo, CETESB, p. $1-61$.

Chae KJ, Jang A, Yim SK, Kim IS (2008) The effects of digestion temperature and temperature shock on the biogas yields from the mesophilic anaerobic digestion of swine manure. Bioresource Technology 99: 1-6. DOI: https://doi.org/10.1016/j.biortech.2006.11.063.

Chen YR (1983) Kinetic analysis of anaerobic digestion of pig manure and its design implications. Agricultural Wastes 8(2): 65-81. DOI: https://doi.org/10.1016/01414607(83)90105-1.

Chernicharo CA (2016) Reatores anaeróbios. Belo Horizonte, Editora UFMG, 2 ed ampl. 379p.

CIBIOGÁS-ER - Centro Internacional de Energias Renováveis - Biogás (2009) Manual de Equações e Metodologias do Simulador. Plataforma de Informações para Energias Renováveis. Foz do Iguaçu, CIBiogás-ER.

Coluna NM (2016) Análise do potencial energético dos resíduos provenientes da cadeia agroindustrial da proteína animal no Estado de São Paulo. Magister Scientiae Thesis, Instituto de Energia e Ambiente, Universidade de São Paulo.

Deng L, Yang H, Liu G, Zheng D, Chen Z, Liu Y, Lei, Y (2014) Kinetics of temperature effects and its significance to the heating strategy for anaerobic digestion of swine wastewater. Applied Energy 134: 349-355. DOI: https://doi.org/10.1016/j.apenergy.2014.08.027.

Fernandes Filho AC, Santana CO, Gattamorta MA (2018) Utilização de biodigestores para geração de energia elétrica a partir de dejetos de suínos no Brasil. Inovae 6: 67-84. ISSN: 2357-7797.
Ferreira, NA. de L., Aires, KO, Almeida, MV. de A., Melo, MC, Monteiro, VED. (2017). Avaliação das concentrações de metano gerado em um biorreator de bancada com base em parâmetros físico-químicos. Engenharia Sanitária Ambiental 22(3): 473-479. DOI: https://doi.org/10.1590/S1413-41522017145766.

Freitas FF, Souza SS, Ferreira LR, Otto RB, Alessio FJ, Souza SN, Ando Junior OH (2019) The Brazilian market of distributed biogas generation: Overview, technological development and case study. Renewable and Sustainable Energy Reviews 101: 146-157. DOI: https://doi.org/10.1016/j.rser.2018.11.007.

Hashimoto AG, Varel VH, Chen YR (1981) Ultimate methane yield from beef cattle manure: Effect of temperature, ration constituents, antibiotics and manure age. Agricultural Wastes, 3(4): 241-256. DOI: https://doi.org/https://doi.org/10.1016/01414607(81)90011-1.

IPCC - Intergovernmental Panel on Climate Change (2006) Emissions from Livestock and manure management. In: Hongmin Dong, Joe Mangino, A R (Russian F. Jerry L. Hatfield, Donald E. Johnson, Keith R. Lassey, Magda Aparecida de Lima (Eds.), IPPC Guidelines for National greenhouse gas inventories. Hongmin Dong, p.10.1-10.87.

Kafle GK, Chen L (2016) Comparison on batch anaerobic digestion of five different livestock manures and prediction of biochemical methane potential (BMP) using different statistical models. Waste Management 48: 492502. DOI: https://doi.org/10.1016/j.wasman.2015.10.021.

Kunz A, Oliveira PAV (2006) Aproveitamento de dejetos de animais para geração de biogás. Revista de Política Agrícola 15(3): 28-35.

Li P, Li W, Sun M, Xu X, Zhang B, Sun Y (2019)

Evaluation of biochemical methane potential and kinetics on the anaerobic digestion of vegetable crop residues.

Energies 12(26): 1-14. DOI:

https://doi.org/10.3390/en12010026.

Lobato LC, Chernicharo CA, Souza CL (2012) Estimates of methane loss and energy recovery potential in anaerobic reactors treating domestic wastewater. Water Science and Technology 66 (12): 2745-2753. DOI: https://doi.org/10.2166/wst.2012.514.

Majdinasab A, Zhang Z, Yuan Q (2017) Modelling of landfill gas generation. a review. Review Environmental Science Biotechnology, 16(April): 361-380. DOI: https://doi.org/10.1007/s11157-017-9425-2

Metcalf L, Eddy HP (2016) Tratamento de efluentes e recuperação de recursos. McGraw Hill Brasil. 
Mito JY, Kerkhoff S, Silva JL, Vendrame MG, Steinmetz RL, Kunz A (2018) Metodologia para estimar o potencial de biogás e biometano a partir de plantéis suínos e bovinos no Brasil (Documentos). Concórdia : Embrapa Suínos e Aves: Concórdia, Embrapa Suínos e Aves.

Nandorf RJ, Monaco PAVL, Haddade IR, Paula LIS, Salla PH, Vieira GHS (2021) Performance of filters composed of banana stalk in swine. Rev. Caatinga, 34(2): 479-485. DOI: https://doi.org/http://dx.doi.org/10.1590/1983-

$21252021 v 34 n 224 r c$

Ramírez-Islas ME, Güereca LP, Sosa-Rodriguez, FS, Cobos-Peralta, MA (2020) Environmental assessment of energy production from anaerobic digestion of pig manure at medium-scale using life cycle assessment. Waste Management 102: 85-96. DOI:

https://doi.org/10.1016/j.wasman.2019.10.012.

Rodrigues L S (2008) Concepção e avaliação de sistema de tratamento com reator anaeróbio de manta de lodo (UASB) e lagoa de polimento para águas residuárias de suinocultura. PhD Thesis, Universidade Federal de Minas Gerais, Escola de Veterinária.

Rosa AP, Lobato LC, Chernicharo CA (2020) Mathematical model to predict the energy potential of UASB-based sewage treatment plants. Brazilian Journal of Chemical Engineering 37(1): 73-87. DOI:

https://doi.org/10.1007/s43153-020-00012-2.

Santos EL, Nardir Junior G (2013) Produção de biogás a partir de dejetos de origem animal. Tekhne e Logos 4(2): 81-90.
Sousa I P, Rosa A P, Borges AC, Renato NS (2020) Energy potential of biogas from pig farms in the state of Minas Gerais, Brazil. Engenharia Agrícola 40(3): 396404. DOI: http://dx.doi.org/10.1590/1809-4430Eng.Agric.v40n3p396-404/2020.

Souza CL, Chernicharo CAL, Aquino SF (2011) Quantification of dissolved methane in UASB reactors treating domestic wastewater under different operating conditions. Water Science and Technology 64(11): 22592264. DOI: https://doi.org/10.2166/wst.2011.695.

Souza JC, Oliveira PA, Tavares JM, Filho, PB, Zanuzz, CM, Tremea, SL, Amaral N (2016) Gestão da água na suinocultura. Concórdia, Embrapa Suí

Xavier AC, King CW, Scanlon BR (2016) Daily gridded meteorological variables in Brazil (1980-2013).

International Journal of Climatology 36(6): 2644-2659. DOI: https://doi.org/10.1002/joc.4518.

Yang H, Deng L, Liu G, Yang D, Liu Y, Chen Z (2016) A model for methane production in anaerobic digestion of swine wastewater. Water Research 102: 464-474. DOI: https://doi.org/10.1016/j.watres.2016.06.060.

Yu H, Wilson F, Tay J (1998) Kinetic analysis of an anaerobic filter. Water Research 32(11): 3341-3352 PII: S0043-1354(98)00102-X.

Zilotti HA (2012) Potencial de produção de biogás em uma estação de tratamento de esgoto de Cascavel para a geração de energia elétrica. Magister Scientiae Thesis, Universidade Estadual do Oeste do Paraná, Centro de Ciências Exatas e Tecnológicas. 